\title{
Геолого-вещественные особенности
} кимберлитовых диатрем

\section{Н.Н. Зинчук}

Западно-Якутский научный центр (ЗЯНЦ) Академии наук Республики Саха (Якутия), 678170, Мирный, ул. Ленина, 4/1

E-mail:nnzinchuk@ rambler.ru

(Статья поступила в редакиию 16 августа 2016 г.)

Исследования геологического строения и вещественного состава кимберлитов Сибирской платформы показали сложность и многообразие геологотектонических и палеогеографических обстановок, которые следует учитывать при постановке прогнозно-поисковых работ на алмазы в каждом конкретном регионе. Для поисков кимберлитовых тел в различных геолого-тектонических условиях важно знание вещественного состава как искомых диатрем, так и вмещающих, и перекрывающих их осадочных и магматических образований. Каждый алмазоносный район характеризуется определенным комплексом типоморфных ассоциаций первичных и вторичных минералов кимберлитов. В преобладающем большинстве кимберлитовых трубок преобладают алмазы с ультраосновной ассоциацией включений твердых фаз (оливин, хромшпинель, пироп и др.).

Ключевые слова: кимберлиты, трубки, Сибирская платформа, алмазоносный

DOI: 10.17072/psu.geol.33.70 район, типоморфизм минералов, алмазы.

\section{Введение}

Многими исследователями отмечалась приуроченность коренных месторождений алмазов мантийного происхождения к древним кратонам, консолидация которых завершилась в архее [5-7, 14-16, 19-24, 27]. Это отражено в известном правиле Клиффорда, согласно которому кимберлиты могут быть распространены и в пределах протерозойских подвижных поясов, но их алмазоносность должна быть весьма ограниченной или эти породы могут вовсе не содержать алмазы. До последнего времени в краевых частях кратонов не были встречены коренные месторождения алмазов с промышленными концентрациями, хотя россыпи этого минерала с неустановленными коренными источниками наблюдались на многих платформах мира [1-4, 13, 23]. Однако были открыты ко- ренные месторождения алмазов и в периферийных частях древних кратонов (лампроитовая трубка Аргайл в Западной Австралии, алмазоносные кимберлитовые диатремы Восточно-Европейской платформы и др.).

Такие коренные месторождения алмазов имеют целый ряд особенностей, на основании которых можно выделить самостоятельные алмазоносные зоны, обрамляющие центральные районы практически всех алмазоносных провинций.

Особенности локализации коренных месторождений алмазов в пределах таких зон рассмотрим на примере Сибирской платформы (СП) и особенно её северной части, - Якутской кимберлитовой провинции (ЯКП), протягивающейся с юга на север на 1500 км (от Малоботуобинского алмазоносного района до моря Лаптевых) и с запада на восток на 1000 км (от Хара- 
майского кимберлитового поля в Красноярском крае до р. Лены). На севере и востоке границами алмазоносной провинции служат Лено-Анабарский и АнгароВилюйский прогибы, а на юго-востоке Ангаро-Вилюйский прогиб и Вилюйская синеклиза. На западе граница проходит по восточному борту Тунгусской синеклизы.

\section{Минерагенические подразделения Якутской провинции}

В пределах ЯКП на площади свыше 800 тыс. км² открыто более 1000 кимберлитовых трубок и дайкоподобных тел, распределенных неравномерно и сгруппированных в более чем 25 кимберлитовых полей, которые в свою очередь объединяют в 9 алмазоносных районов.

\section{Минерагенические субпровинции}

По особенностям геолого-тектонического положения отдельных групп кимберлитовых пород, их минералогопетрографическим характеристикам, возрасту, петрохимии, геохимии, кристалломорфологическим особенностям алмазов и алмазоносности отдельные исследователи [1-3, 14, 27-29] разделяют ЯКП на две субпровинции: Вилюйскую и АнабароОленекскую. Понятие «субпровинция» было введено из-за неравномерности внедрения глубинных магматитов в другие образования платформы [10-12]. Практически на всех древних платформах мира наблюдается скученность групп кимберлитовых полей в одних частях при полной амагматичности других территорий. В пределах субпровинции магматические тела ультраосновных и щелочных пород группируются в поля, обьединяющие в своих границах десятки и сотни магматических тел. Обычно магматические тела различной фациальной принадлежности локализованы в своих полях: кимберлиты в кимберлитовых, карбонатиты в карбонатитовых, лампроиты в лампроитовых.
На отдельных территориях древних платформ (северо-восточная часть СП, юг Африканской платформы и др.) отмечен «полихронный магматизм». В таких разновозрастных кимберлитовых формациях существенных различий как по петрохимическим $[2,6]$, так и по соотношению первичных мантийных минералов [13-15, 28] не установлено. Не отмечено это и в более мелких таксономических единицах кимберлитовых субпровинций, которыми являются алмазоносные районы или поля.

Вилюйская кимберлитовая субпровинция охватывает территорию, южной границей которой являются контуры Малоботуобинского алмазоносного района (МБАР). Северная граница субпровинции совпадает с северным ограничением Верхнемунского района и условно проводится на широте излучины р. Оленек. Территория субпровинции вытянута с юга на север на 800 км. В её составе выделены четыре алмазоносных района: Малоботуобинский, Далдыно-Алакитский, Верхнемунский и Среднемархинский, в которых обособляются шесть кимберлитовых полей, три из которых (Далдынское, АлакитМархинское и Моркокинское) находятся в Далдыно-Алакитском алмазоносном районе (ДААР).

Анабаро-Оленекская кимберлитовая субпровинция охватывает большую территорию северной части ЯКП, располагающуюся в бассейне рек Оленек и Анабар. Восточной границей условно можно считать р. Лену, западной - Анабарский щит, а на севере она протягивается до Ледовитового океана. В пределах этой субпровинции выделяются пять алмазоносных районов: Среднеоленекский, Нижнеоленекский, Приленский, Анабарский (или Куонапский) и Котуй-Меймечинский. Каждый из них включает отдельные кимберлитовые поля с многочисленными трубками, дайками, силлами и жилами.

\section{Минерагенические зоны}

Таксоном, соподчиненным кимберлитовой субпровинции, принято считать 
кимберлито-контролирующую (или минерагеническую) зону, выделение которой в качестве самостоятельной таксономической единицы основано на линейнодискретном пространственном расположении полей глубинных магматитов [2326]. Примером линейного расположения групп кимберлитовых полей является северо-восточная часть Якутской минерагенической провинции (ЯМП), в пределах которой принято выделять две зоны: Оленекскую и Куонамскую.

Оленекская зона объединяет Чомурдахское, Восточно-Укукитское, ЗападноУкукитское, Мерчимденское, Толуопское, Молодинское и Куойское кимберлитовые поля в полосе северо-восточного простирания размером 350x80 км. Магматические комплексы в пределах этой зоны представлены кимберлитами двух возрастных генераций - среднепалеозойской $\left(\mathrm{D}_{3}-\mathrm{C}_{1}\right)$ и мезозойской $\left(\mathrm{J}_{3}-\mathrm{K}_{1}\right)$. Находки парагенетических индикаторных минералов-спутников алмаза (ИМК) в терригенных отложениях позднего докембрия не исключают обнаружение и более ранних протерозойских магматических кимберлитовых комплексов [15]. Северовосточная часть этой зоны характеризуется полихронным магматизмом с учетом пространственного сонахождения разновозрастных комплексов.

Куонапская зона расположена вдоль флангов Анабарского щита, огибая его восточные границы. В её пределах (300x30 км) расположены Старореченское, Орто-Ыаргинское, Ары-Мастахское, Лучаканское и Дьюкенское кимберлитовые поля, обьединяющие группы широкой формационной принадлежности, чем они существенно отличаются от Оленекской зоны. В составе магматического комплекса здесь развиты кимберлиты, карбонатиты, альнеиты и другие труднодиагностируемые разновидности, относимые многими исследователями к щелочным пикритам [23]. Большинство исследователей принимают возраст кимберлитового магматизма Куонапской зоны как мезозойский $\left(\mathrm{T}_{3}-\mathrm{J}_{1}\right)$. Есть мнение и о более широком возрастном диапазоне внедрения магматических пород [22, 27-30].

\section{Кимберлитовое поле}

В качестве таксона, соподчиненного минерагенической зоне, нередко используется понятие «кимберлитовое поле», вмещающее и другие конвергентные породы. Выделение поля магматических тел в качестве самостоятельной таксономической единицы основано на их эмпирически выявленном универсальном свойстве группироваться в ограниченном пространстве в границах перспективных минерагенических зон. Генетические особенности выделения кимберлитовых полей связаны со свойствами магматических тел глубиной формирования, способностью группироваться в пространственно разобщённые сообщества. Линейные разрезы таких участков изменяются от первых десятков до сотни километров при достаточно устойчивой средней плотности расположения магматических тел в плане. Вариации вещественного состава магматитов в границах поля по петрологическим, минералогическим и геохимическим характеристикам обычно незначительны. В структурно-тектоническом плане кимберлитовое поле - это область пересечения нескольких (как минимум двух) систем разрывных нарушений [4, 12, 22-25].

\section{Модельные типы поисковых ал- мазоносных площадей}

От геолого-геофизических особенностей залегания кимберлитовых диатрем во многом зависят их прогнозирование и поиски. Это проиллюстрируем на примере основных районов ЯАП СП, которые можно разделить на типы площадей, определяемые следующим: а) кимберлитовые трубки полностью перекрыты верхнепалеозойскими отложениями или траппами; б) частично перекрыты верхнепалеозойскими отложениями или траппами; в) полностью перекрыты мезозойскими 
отложениями; г) прорваны траппами без существенного перемещения отторгнутых блоков; д) прорваны траппами с отторжением и перемещением блоков кимберлитов; е) представляют протрузии кимберлитовых тел в верхнепалеозойские отложения и траппы; ж) сохранили в верхних частях кратерные фации; 3) характеризуются эксплозивной камерой закрытого типа; и) покрыты маломощными элювиальными и делювиальными образованиями.

С наибольшей эффективностью поисковые работы на территории ЯКП проведены на открытых площадях и в областях развития протерозойских, нижнепалеозойских и четвертичных отложений $[5,9$, 24]. Их результативность во многом зависела от чёткого представления о типовых моделях основных объектов поисков кимберлитовых трубок [3, 16-18]. При определении моделей для известных кимберлитовых тел очень важны характер взаимоотношения их с перекрывающими породами и геолого-структурные условия формирования самих диатрем. Поэтому основными типами таких поисковых моделей можно считать кимберлитовые трубки, перекрытые верхнепалеозойскими и мезозойскими отложениями, а также выходящие непосредственно на поверхность земли. Поскольку модельными и наиболее изученными являются кимберлитовые диатремы СП, которые могут встречаться и на других древних платформах мира, то целесообразно дать геолого-вещественную характеристику всех отмеченных типов поисковых площадей.

\section{Кимберлитовые трубки, полностью пе- рекрытые верхнепалеозойскими отло- жениями и траппами}

Они составляют около 40\% диатрем, открытых в Алакит-Мархинском поле (АМКП). Практически все (за исключением трубки Лира) кимберлитовые трубки этого поля были зафиксированы с помощью площадного бурения по сети различной плотности и проводимого при этом шлихо-минералогического опробования перекрывающих эти тела отложений. Сравнительно низкая эффективность применяющихся при поисках здесь геофизических и геохимических методов обусловлена отсутствием надежных прогнозно-поисковых критериев, а также сложностью расшифровки геофизических полей на площадях развития пород трапповой формации. Поэтому в таких сложных геолого-структурных ситуациях основным методом поисков алмазных месторождений является шлихо-минералогический, главная задача которого - выделение древних ореолов рассеяния продуктов дезинтеграции кимберлитов с последующей локализацией таких образований бурением скважин, сопровождающимся шлиховым опробованием вскрываемых разрезов и комплексными геологогеофизическими исследованиями скважин.

В целом эффективность применения указанного комплекса методов в значительной мере зависит от условий осадконакопления в посткимберлитовую эпоху, позволяющих сохранить следы размыва кимберлитовых тел и их природного разнообразия, условий формирования и строения их верхних (кратерных) частей, взаимоотношения с перекрывающими и интрудирующими их породами и др. Нередко поверхности кимберлитовых трубок на таких участках перекрываются верхнепалеозойскими терригенными (а иногда и туфогенными) отложениями, в различной степени интрудированными силлами траппов. Иногда непосредственно на поверхности кимберлитовых тел и вмещающих пород залегают траппы [4, 24].

Мощность перекрывающих трубки верхнепалеозойских отложений в ДААР колеблется от первых метров до 130. От 5 до 100 м на этой территории меняется и мощность прорывающих кимберлитовые трубки трапповых образований. Отмечены также значительные (до 100 м и более) мощности трапповых тел, непосредственно бронирующих поверхности кимберлитовых тел. Северней (уже в ДААР) наибо- 
лее характерны следующие взаимоотношения кимберлитовых трубок с полностью перекрытыми верхнепалеозойскими отложениями и траппами:

a) траппы в виде маломощных силлов (иногда апофиз от них) интрудируют верхние горизонты перекрывающих трубки отложений, будучи приуроченными к краевым частям диатрем (трубки Восток, Байтахская и др.);

б) в перекрывающих трубки породах траппы располагаются на двух уровнях: верхний силл в виде мощного (до 70 м) траппового тела бронируют с поверхности осадочные породы верхнего палеозоя, а нижний (сравнительно маломощный) внедряется по контакту этих пород с кимберлитовмещающими отложениями нижнего палеозоя или интрудирует верхнюю часть кимберлитовых тел (трубки Краснопресненская, Подтрапповая и др.);

в) трапповые покровы, бронирующие отложения пермокарбона, которые, приближаясь к кимберлитовым трубкам, существенно изменяют свою мощность, расщепляются на серию мелких апофиз, создавая над поверхностью погребенных тел своеобразные «окна» (трубки Юбилейная, Кыллахская и др.);

г) трапповый силл внедряется по границе между верхне- и нижнепалеозойскими отложениями (трубка Алакитская и др.), причём в таких случаях в краевой части диатремы силлом отслаиваются и перемещаются в горизонтальном направлении блоки кимберлитов вместе с вмещающими их карбонатными и терригенно-карбонатными породами;

д) силлы долеритов, внедряясь в отложения нижнего палеозоя, налегают на палеоповерхность кимберлитовых тел, уничтожая при этом следы размыва последних и ограничивая тем самым возможность применения шлихоминералогического метода для поисков алмазных месторождений.

На практике отмечается несколько характерных типов пересечений кимберлитовых тел силлами долеритов, в которых имеет место нарушение их целостности путём перемещения блоков кимберлитов от первоначального залегания до нескольких сотен метров [15]. Известны случаи, когда кимберлиты образуют «протрузию» в породы верхнего палеозоя и траппы. При этом иногда (трубка Москвичка и др.) они оказываются на современной поверхности и находятся на одном и том же гипсометрическом уровне с траппами и породами верхнего палеозоя.

Типичным модельным объектом кимберлитов, перекрытых терригенными отложениями верхнего палеозоя и частично траппами, можно считать трубку Восток [30]. В разрезе перекрывающих эту трубку пород пермокарбона преобладают песчаники, алевролиты и углисто-глинистые сланцы, которые интрудированы несколькими горизонтально-секущими интрузиями траппов. Суммарная мощность перекрывающих трубку отложений составляет в среднем 33 м. Трапповые тела распространены над трубкой неповсеместно и приурочены в основном к её северовосточной и юго-западной частям. В пределах северо-западного фланга трубки в составе перекрывающих её пород вскрыто до четырех маломощных (от 0,4 до 8 м) трапповых тел. По данным колонкового бурения поверхность трубки образует овал субширотного простирания. Учитывая, что по петрофизическим свойствам кимберлитовые породы значительно уступают вмещающим терригеннокарбонатным породам нижнего палеозоя, такая положительная форма поверхности диатремы имеет большое прогнознопоисковое значение [15]. Подобные формы поверхности диатрем встречены и в других трубках ДААР (Сытыканская, Победа и др.). Трубка Восток сложена двумя генетическими разновидностями кимберлитовых пород - резко доминирующей автолитовой кимберлитовой брекчией (АКБ) и порфировым кимберлитом (ПК). В верхней части диатремы установлена кора выветривания (КВ) кимберлитов мощностью 15-20 м. Непосредственно под перекрывающими трубку породами вскрыт выветрелый рассланцованный 
кимберлит, представляющий собой рыхлую глинистую породу, содержащую повышенное количество измененных ксенолитов карбонатных пород. Иногда здесь встречаются раздробленные зёрна ильменита, пиропа и измененные слюдистые чешуйки. Породы в этой части разреза пропитаны гидроксидами железа, придающими им бурую окраску. Кратерная и частично диатремовая части трубки сильно эродированы, что привело к её размыву и переотложению кимберлитового материала в бассейны накопления прилегающих к диатреме каменноугольнопермских отложений. Трубка открыта при изучении гравийного базального слоя верхнепалеозойского разреза, обогащенного зернами ильменита, пиропа и чешуйками в различной степени измененного флогопита.

С использованием этих же индикаторных минералов в подобной поисковой обстановке была открыта в 1955 г. трубка Сытыканская. Первоначально предполагалось, что трубка Сытыканская представляет собой незначительное по размерам и выходящее на дневную поверхность тело, расположенное непосредственно у самого уступа траппового плато. Однако в процессе дальнейших поисковооценочных работ было установлено, что большая часть трубки перекрыта терригенными породами пермского возраста, бронированными мощной интрузией траппов. После этого в ДААР начались систематические поиски погребенных кимберлитовых трубок, в том числе и на площадях развития пород трапповой формации. Трубка Сытыканская состоит из двух самостоятельных тел - северовосточного (основного) и юго-западного. По форме и условиям залегания трубка представляет сдвоенное тело, сильно вытянутое с юго-запада на северо-восток. Расстояние по поверхности между обоими телами составляет 30 м, существенно увеличиваясь с глубиной. Некоторые исследователи предполагают, что до эрозии верхние части кимберлитовых тел соприкасались друг с другом. Северо-восточное тело в плане характеризуется неправильной чётковидной формой, с пережимами и выступами. В разрезе это крутопадающее тело с закономерным сужением на глубину. Юго-западное тело диатремы имеет форму вытянутого эллипса. По размерам оно значительно уступает северовосточному. С поверхности юго-западное тело и преобладающая часть северовосточного перекрыты терригенными отложениями пермокарбонового возраста, залегающими на размытой поверхности самих тел, и мощным трапповым силлом, представляющим собой краевую часть огромного траппового плато $[3,14]$. Лишь небольшой участок (площадью первые проценты трубки) был выведен эрозией на дневную поверхность и перекрыт маломощными элювиально-делювиальными осадками. Мощность перекрывающих трубку терригенных пермокаменноугольных пород озерно-болотной фации колеблется от 9 до 16 м. Выше этих отложений над большей частью трубки залегают долериты. В юго-западной части диатремы, где терригенные отложения выклиниваются, эти магматические трапповые образования лежат непосредственно на поверхности кимберлитов и вмещающих их терригенно-карбонатных пород нижнего палеозоя. Мощность траппов непосредственно в районе трубки Сытыканская варьирует от 5 (на северо-восточном фланге) до 87 м (на юго-западе и в центральной части). За контуром трубки она резко возрастает, достигая в отдельных участках до 125 м. Оба тела трубки Сытыканская сложены типичной кимберлитовой брекчией, в которой большинство исследователей выделяют три разновидности [1-4]. Северо-восточное тело представлено породами двух фаз внедрения, образующими два самостоятельных рудных столба центральный и северо-восточный, сочленяющихся между собой через переходную зону [15]. Юго-западное тело имеет относительно простое строение и сложено породами одной фазы внедрения. В пределах основного тела трубки различаются кимберлитовые брекчии с массивной тек- 
стурой цемента первой фазы внедрения и АКБ второй - завершающей - фазы. Непосредственно под толщей перекрывающих трубку терригенно-карбонатных отложений пермокарбона отмечается кимберлитовая брекчия, участками сильно выветрелая, представляющая собой типичную остататочную КВ. Вмещающий трубку разрез представлен (в пределах верхней изученной части) карбонатными и терригенно-карбонатными породами верхнего кембрия, нижнего и среднего ордовика, а на отдельных участках - нижнего силура. Контакты кимберлитовых пород c вмещающими образованиями обычно резкие и чёткие. На отдельных участках вмещающие породы на контактах с кимберлитами раздроблены и брекчированы. Мощность таких зон колеблется от 0,5 до 5,0 м, достигая в отдельных случаях 12 м. Иногда отмечаются чётко выраженные участки термального воздействия кимберлитового расплава и его гидротермальных растворов на вмещающие породы, выражающегося в их заметном уплотнении, частичном ороговиковании и изменении окраски.

\section{Кимберлитовые трубки, полностью пе-} рекрытые мезозойскими отложениями

Они установлены в МБАР и Среднемархинском алмазоносных районах (СМАР) СП, хотя возраст самих кимберлитов датируется большинством исследователей этих территорий как среднепозднепалеозойский. В МБАР к ним отнесены трубки Интернациональная, им. ХХШ сьезда КПСС и Дачная, открытые с помощью применяемого в ЯКП комплекса геолого-геофизических методов. Эти диатремы имеют небольшие размеры, но характеризуются высоким качеством алмазов, большая часть которых относится к ювелирным.

Трубка Интернациональная, расположенная в 16 км к юго-западу от трубки Мир на правобережье р. Ирелях (в верхнем течении её правых притоков Маччоба-Салаа и Улаах-Юрях), тяготеет к За- падному региональному разлому [1-3]. Кимберлитовая трубка Интернациональная внедрилась в осевую зону Кюэляхского разлома и сопровождается системой даек, ориентированных в северовосточном, северо-западном и почти меридиональном направлениях [4, 13-15]. На поверхности трубка имеет форму неправильного овала, вытянутого на северозапад. В результате разведки диатремы до 955 м установлено, что в среднепалеозойское и мезозойское время около 470 м верхней части диатремы было уничтожено в результате длительной эрозии, в результате чего от раструба сохранилась только его нижняя 120-метровая часть. Далее на глубину остатки раструба переходят в цилиндрический почти вертикальный канал. До разведанной глубины размеры трубки существенно не уменьшаются, стабильной остаётся и продуктивность пород [30]. Диатрема прорывает горизонтально залегающие терригеннокарбонатные породы нижнего ордовика и кембрия, перекрываясь нижнеюрскими отложениями мощностью от 2,1 до 9,2 м. В верхней части трубки Интернациональная залегают слоистые породы с чередованием прослоев мелко- и крупнопорфирового кимберлита. Прослои (до 5 см) сложены различными по размеру зёрнами измененного оливина, пиропа и пикроильменита. В мелкопорфировых кимберлитах количество псевдоморфоз серпентина и кальцита по оливину не превышает $20 \%$, тогда как в крупнопорфировых оно достигает 50-60\% обьема породы. Размер минералов в мелкопорфировых слоях равен 0,3-0,8 мм, а в крупнопорфировых до 7-8 мм. В верхних горизонтах трубки выделяются два типа пород - кимберлитовые брекчии, которые преобладают (до 99\%), и массивные кимберлиты. Из ксенолитов наиболее распространены (5$15 \%$ ) обломки терригенно-карбонатных пород. В породе присутствуют также единичные обломки траппов и кристаллических сланцев фундамента платформы. Повышенное количество (40-60\%) ксенолитов терригенно-карбонатных пород фик- 
сируется в приконтактовой зоне (особенно на участках пологого залегания контактов кимберлитов с вмещающими образованиями). Для верхних частей трубки (до 370 м) характерно относительно высокое содержание примеси терригенного материала вмещающих пород, представленного песчаной, алевритовой и глинистой фракциями, состоящими из кварца, полевых шпатов, турмалина, ставролита, сфена и других устойчивых минералов. Глубже количество этих минералов резко снижается до полного исчезновения на самых глубоких частях трубки.

Относящаяся к этому же геологопоисковому типу кимберлитовая трубка имени ХХШ сьезда КПСС расположена в 14 км к юго-западу от трубки Мир и приурочена к Западному региональному разлому. Она полностью перекрыта 12-20метровой толщей нижнеюрских терригенных отложений, в которых выделены две пачки: нижняя, отнесенная к укугутской свите, и верхняя - к домерскому ярусу [30]. На поверхности трубка имеет размер $120 x 80$ м. Форма её овальная, длинная ось ориентирована в северо-западном направлении. В верхней части трубка имеет крутопадающие контакты, которые уже на глубине 100 м заметно выполаживаются, принимая дайкообразную форму на глубине 150 м. Рельеф трубки под осадками нижней юры неровный. В южной части наблюдается отчетливо выраженная возвышенность с превышением кимберлитов на 10-12 м над поверхностью вмещающих пород нижнего палеозоя. Перекрывающие трубку породы слагают своеобразную антиклинальную складку. Прорывает диатрема горизонтально залегающие терригенно-карбонатные отложения нижнего ордовика и кембрия. В северо-восточной части трубки под нижнеюрскими отложениями сохранилась древняя КВ кимберлитов мощностью 8-12 м, в глинистой части которой преобладает монтмориллонит с примесью каолинита, гидрослюды, хлорита и серпентина [10-12,15]. Из первичных минералов в выветрелом кимберлите встречены пироп, пикроильменит и хро- мит. Отмечена характерная особенность увеличения в КВ, по сравнению с плотным кимберлитом, концентрации алмаза, пикроильменита и хромшпинелида. Количество пиропа в измененном кимберлите несколько меньше, чем в плотной породе, что связано с его растворением под действием гипергенных процессов. Отмечена сильная химическая коррозия зерен пиропа, выразившаяся в появлении на поверхности зерен минерала правильных структур, а также каверн и каналов травления. Часть зёрен минерала приобрела не свойственную им псевдокристаллографическую огранку в виде своеобразных кубоидов, которые не встречены в неизмененной породе. Пикроильменит и хромшпинелид в гипергенных условиях более устойчивы, чем пироп, но и на них в отдельных случаях видны следы коррозии. Алмазоносность кимберлитов трубки исключительно высокая, причём в пределах плотного кимберлита она распределена относительно равномерно. В то же время содержание алмазов в КВ кимберлитов более чем в 6 раз выше по сравнению с плотной породой. Среди алмазов рассматриваемой диатремы преобладают октаэдры (более 75\%); более 6\% составляют ромбододекаэдры и около $20 \%$ кристаллов - комбинационные формы [13]. Редко встречаются кубические кристаллы. Подавляющее большинство зерен алмазов в плотных кимберлитах трубки относятся к бесцветным разностям, в то время как в КВ этих же пород преобладают кристаллы, окрашенные в цвет морской волны, что может быть связано с постмагматическими изменениями минерала.

Недалеко от описанной диатремы находится кимберлитовая трубка Дачная, приуроченная к Параллельному разлому. Она перекрыта нижнеюрскими осадочными толщами мощностью 15-21 м. Рельеф под перекрывающими диатрему нижнеюрскими отложениями неровный, с превышением до 6 м. Размеры трубки на поверхности 120x100 м. Форма её близка к овалу, длинная ось которого ориентирована в северо-западном направлении. На 
глубине 105 м от поверхности площадь горизонтального сечения трубки уменьшается примерно в два раза. Самая верхняя часть представлена сильно измененной породой КВ, практически лишённой первичной материнской структуры. Глубже залегают выветрелый кимберлит, полностью сохраняющий структуру исходной породы. В составе продуктов выветривания преобладают монтмориллонит, ассоциирующий с каолинитом, гидрослюдой, хлоритом и серпентином. С глубины 65 м и ниже развиты сравнительно менее изменённые кимберлитовые брекчии. Встречаются обломки терригенно-карбонатных пород, отдельные зерна кварца, полевых шпатов и других в различной степени измененных минералов. Редки обломки траппов и кристаллических сланцев фундамента платформы, сцементированные кимберлитовым материалом, состоящим из псевдоморфоз монтмориллонита, серпентина и карбонатов по оливину, относительно редких зерен пиропа, пикроильменита и хромшпинелида, заключенных в агрегате серпентин-монтмориллонит-карбонатного состава. При почти равномерном распределении алмазов в диатреме несколько снижается их содержание в приконтактовых частях трубки. Преобладают октаэдры (47\%) и комбинационные формы минерала (около $40 \%$ ) при подчиненной роли (около $12 \%$ ) ромбододекаэдров.

К этому же геолого-поисковому типу относятся диатремы Накынского кимберлитового поля, открытого в пределах CMAР, охватывающего территорию среднего течения р. Мархи и верхнего течения p. Тюкян (левого притока р.Вилюй). Геолого-структурные особенности этого района определяются его приуроченностью к зоне сочленения кратонной и депрессионно-деструктивной областей центральной части СП $[15,19,27]$. Основными структурами кратонной области, в пределах которой открыты кимберлитовые трубки Ботуобинская, Нюрбинская и тело Майское, являются: на севере - южная оконечность Анабаро-Оленекской антеклизы, на северо-западе - Сюгджерская седловина и на юго-востоке - северная часть Вилюйской синеклизы. В качестве таксона этого поля рассматривается тектонический блок (20x30 км), разделённый в свою очередь разломами на два примерно одинаковых по площади блока. Последние ограничены относительно крупными зонами ортогональных разломов, которые хорошо выделяются по результатам интерпретации магнитного и гравитационного наземных полей, а также по аэромагнитным данным. Разломы имеют северовосточное и северо-западное простирание. Первые из них являются более протяженными и прямолинейными, вторые - часто прерывистыми, в плане - дуго- и кулисообразными. Выполнены разломы обоих направлений крутопадающими дайками долеритов. Нарушения северо-восточного простирания представляют собой отдельные ветви гигантской системы разломов Вилюйско-Мархинского пояса среднепалеозойского возраста. Рассматриваемый тектонический блок поля располагается в осевой части пояса. Структура рудного узла трубок Ботуобинская и Нюрбинская характеризуется проявлением локальных разрывных дислокаций, картируемых во вмещающих их осадочных толщах в пределах околотрубочного пространства. Трубка Ботуобинская расположена в истоках руч. Дьяхтар-Юрэгэ (левого притока р.Мархи), в поле сплошного развития раннеюрских осадочных толщ (мощностью до 80 м), и относится к числу полностью погребенных кимберлитовых тел [30]. Диатрема является сложным сдвоенным кимберлитовым телом, южная часть которого представляет собой дайкообразное образование северо-восточного простирания, а северо-восточная - имеет форму овала. В месторождении развиты кимберлиты двух фаз, ранняя из которых представлена ПК, слагающим дайковую часть трубки и не выходящим на дневную поверхность. Более поздняя фаза эксплозивных кимберлитовых брекчий связана с верхней частью дайкообразного образования и вертикальным каналом трубочного 
тела. В верхней части трубочного тела сохранились породы кратерных фаций, известные на некоторых диатремах ДААР [5-7, 13-15]. Наличие кратерных построек, выполненных кимберлитовыми туфобрекчиями (КТБ), свидетельствует о незначительном эрозионном срезе этой трубки. КТБ верхних горизонтов кратера (северо-восточная часть трубки) представляют собой бескорневые кимберлитовые породы начальной эксплозивной стадии формирования диатремы. Их материнской породой являются подстилающие АКБ. В верхних горизонтах трубки установлена остаточная КВ, достигающая в отдельных местах мощности 15-20 м. Трубка Ботуобинская принадлежит к кимберлитовым телам со средним содержанием глубинных индикаторных минералов, среди которых доминирует хромшпинелид-гранатовая ассоциация. По комплексу типоморфных признаков и характеру их связи с крупностью алмазы трубки Ботуобинская не имеют аналогов среди известных кимберлитовых тел ЯАП и мира [8, 13]. Среди основных типоморфных особенностей алмазов отмечается низкое содержание ламинарных ромбододекаэдров и отсутствие типичных округлых алмазов уральского типа. Присутствуют в значительном количестве псевдоромбододекаэдры мархинского типа, псевдокубического габитуса I, а также алмазы с оболочкой IV разновидности [26].

К этой же геолого-поисковой обстановке относится кимберлитовая трубка Нюрбинская, расположенная в Накынском кимберлитовом поле в верховье руч. Дюлюнг-Оту (правый приток р.Накын), в 3,3 км к северо-востоку от трубки Ботуобинская, приуроченная к осевой линии Дьяхтарского разлома. Трубка прорывает алевритисто-глинисто-карбонатные верхнекембрийские и нижнеордовикские отложения и перекрывается чехлом терригенных нижнесреднеюрских отложений (укугутская, тюнгская и сунтарская свиты) и дезинтегрированными продуктами КВ $\left(\mathrm{T}_{2-3}\right)$ общей мощностью 55-60 м. Погребенная поверхность трубки неровная с небольшой выпуклостью вдоль югозападного борта и чашеобразным углублением в центральной части. Для одного из таких участков трубки Нюрбинская установлен сложный структурнотектонический план, поскольку на глубине 124-126,5 м в пределах югозападного фланга выявлено жильное тело кимберлитов [15]. Вблизи юго-западного и восточного бортов вскрыты карстовые полости, заполненные делювиальнооползневыми образованиями (мощностью до 20-42 м) и обогащенные продуктами КВ кимберлитов. Существенным структурным элементом трубки является нарушение целостности рудного тела вследствие его прорыва мощной интрузией траппов субщелочного состава. Эта интрузия представляет собой секущее тело мощностью более 250 м, сложенное мелко- и среднезернистыми долеритами от тёмно-серого до чёрного цвета. Трубка Нюрбинская слагается АКБ, среди которых выделяются мелко-среднеобломоч-

ные брекчии центральной части рудного тела и карбонатная кимберлитовая брекчия приконтактовой зоны северовосточного и юго-западного флангов диатремы. Автолитовые брекчии центральной части трубки представляют собой мелко-среднепорфировые породы зеленовато- или голубовато-серого цвета с автолитовой структурой цемента. В тяжелой фракции кимберлитовых пород трубки преобладают пироп и хромшпинелиды, реже встречаются пикроильменит, оливин и клинопироксен. Для обеих изученных диатрем Накынского поля характерна слабая намагниченность кимберлитов, что затрудняет поиски таких диатрем геофизическими методами. Алмазы из кимберлитов трубки Нюрбинская близки к таковым из Ботуобинской с некоторыми отличиями. В целом алмазы трубки Нюрбинская характеризуются комплексом типоморфных особенностей, свойственных этим минералам из наиболее продуктивных диатрем ЯКП, причём такое соотношение ассоциации октаэдрических кристаллов I разновидности мирнинского ти- 
па и алмазов, окрашенных оболочкой IV разновидности айхальского типа, впервые встречено на этой территории, что свидетельствует о широком диапазоне условий образования алмазов из кимберлитовых тел Накынского поля по сравнению с другими регионами ЯКП и присутствии среди них повышенного количества кристаллов эклогитового парагенезиса $[13,15]$.

\section{Кимберлитовые трубки, прорванные траппами без существенного переме- щения отторгнутых блоков}

Они присутствуют в ДалдыноАлакитском алмазоносном районе ЯАП. Примером таких модельных поисковых объектов являются кимберлитовые трубки Комсомольская, Ленинградская, Сытыканская, Краснопресненская и др. Хорошим и показательным модельным объектом такого поискового типа можно считать трубку Краснопресненскую [30], открытую в верховье р. Алакит и приуроченную к юго-западному флангу центральной рудоконтролирующей зоны, вмещающей более трети всех известных диатрем в Алакит-Мархинском поле. С поверхности трубка полностью перекрыта терригенно-карбонатными толщами пермокарбона, туфогенными отложениями триаса и прорванными породами трапповой формации мощностью в среднем до78 м. В плане под перекрывающими отложениями трубка имеет форму овала. В разрезе она представляет собой асимметричное воронкообразное тело с чётко выраженным раструбом в верхней части. Характерным структурным элементом одного из участков трубки Краснопресненская является установленное здесь компенсационное погружение над- и околотрубочного субстрата, связанное с воздействием на породы осадочного чехла гидротермальных растворов, обусловившее формирование обширной мульды проседания, которое можно считать надежным поисковым признаком на погребенные кимберлиты. Погребенная поверхность трубки неровная, с чашеобразным углублением в её центральной части, заполненным кратерными отложениями. Существенную роль в формировании рельефа поверхности трубки сыграли внедрившиеся в позднепермское-раннетриасовое время секущие тела траппов, интрудировавшие не только перекрывающие породы, но и саму трубку. В составе слагающих её пород выделяются две основные разновидности кимберлитов: туфогенные образования и автолитовые кимберлитовые брекчии, различающиеся по генезису, составу и алмазоносности. Порфировые кимберлиты встречаются в виде отдельных блоков. В верхней части трубки развиты породы кратерной фации. Установлено глубокое физико-химическое превращение кимберлитов под воздействием на них дифференцированных интрузий субщелочного состава $[11,15]$. В ходе гидротермальнометасоматических процессов кимберлиты диатремы изменены, текстурно-структурные признаки материнских пород утрачены. Отсутствие в таких частях основных макропризнаков кимберлитов существенно затрудняет однозначную интерпретацию таких разрезов в процессе документации керна (особенно в его мерзлом виде). Затруднены вопросы идентификации таких пород даже при микроскопическом изучении их в шлифах. Существенно различаются они и по химическому составу [6,11]. Воздействие трапповых гидротерм привело также к значительному преобразованию основных реликтовых минералов кимберлитов, вплоть до полного их уничтожения в отдельных, наиболее измененных участках, поскольку характер таких изменений во многом идентичен преобразованиям ИМК из КВ кимберлитов $[11,15]$.На контакте с долеритами выполняющие кимберлитовую трубку породы претерпели изменения, более интенсивные в висячем боку силла, где от него отходил ряд мелких апофиз, и сравнительно небольшие преобразования в лежащем боку. Наличие зоны закалки и мелкозернистость самого долерита у контакта с вмещающими породами свидетельствуют о незначительном преобразовании их в 
магматическую стадию становления силла. На интенсивность изменения выполняющих до внедрения основной массы пород трубки оказывали такие факторы, как степень неоднородности и место расположения их по отношению к контакту с вмещающими терригенно-карбонатными породами нижнего палеозоя. Поэтому возникшая под влиянием внедрившейся магмы зональность не является стабильной для больших её участков.

Кимберлитовые трубки, прорванные траппами с отторжением и перемещением блоков кимберлитов

Подобные трубки установлены в АМКП ЯКП. Здесь перемещения блоков осадочных пород нижнего и верхнего палеозоя отмечены как в горизонтальном, так и в вертикальном направлениях. Дальность таких перемещений зависит от морфологии трапповых тел и их мощности. Иногда по вертикали она сопоставима с полной мощностью силлов (до 180 м), а по горизонтали может составлять несколько сотен метров. Для материнских кимберлитовых пород, отчленённых и механически отторгнутых от трубок, обычно применяется термин «кимберлитовый отторженец» [5,24]. В пределах АМКП установлены три крупных отторженца, материнскими породами для которых являются трубки Подтрапповая, Юбилейная и Алакитская. Все блоки отторгнутых кимберлитов представляют пластообразные тела, размеры которых обусловлены разной энергетической мощностью внедрившихся трапповых силлов, определившей и разный характер смещения отторгнутых тел [24].

\section{Протрузии кимберлитовых тел в верхнепалеозойские породы и траппы}

Они отмечены в некоторых алмазоносных районах ЯКП (трубки Москвичка, Восток, Сытыканская и др.). Примером «диапиризма» в перекрывающие их терригенно-осадочные породы может слу- жить трубка Москвичка в АМКП. Открыта трубка в 1956 г. по ИМК (пироп и пикроильменит) при прослеживании их ореола на поверхности траппового плато. Установлено [1,24], что между двумя жёсткими массивами (кимберлитовым телом и силлом долеритов) зажата пачка осадочных каменноугольно-пермских пород, слои которых располагаются вертикально по отношению к современной поверхности. Вблизи контакта и непосредственно на самом контакте верхнепалеозойские отложения сильно разрушены и ожелезнены, а местами даже рассланцованы. Мощность этой зоны колеблется от 0,5 до 2 м. В целом кимберлиты трубки Москвичка «проткнули» маломощную толщу верхнепалеозойских отложений с интрудировавшим её долеритовым силлом. Она оказалась на одном гипсометрическом уровне с указанными породами, которые на данном этапе по отношению к кимберлитам являются вмещающими. Причину такого «протыкания» верхнепалеозойских осадочных толщ и траппов можно объяснить увеличением объема кимберлитов после их перекрытия более молодыми породами [11]. Здесь отмечен эффект «диапиризма», который сопровождался «задиром» каменноугольнопермских пород и возникновением своеобразной складки протыкания диапирового типа. Залегание слоёв на крыльях этой «складки» по мере удаления от её «ядра», сложенного кимберлитами, постепенно выполаживается, а мощности их заметно возрастают.

\section{Кимберлитовые трубки с сохранивши- мися кратерными фациями}

Яркими представителями подобных трубок являются Юбилейная, Краснопресненская, Айхал и др. Так, трубка Юбилейная прорывает толщу нижнепалеозойских субгоризонтально залегающих пород осадочного чехла кембрия, нижнего и среднего ордовика и нижнего силура. Она полностью перекрыта эффузивнотерригенными образованиями верхнего 
палеозоя - нижнего мезозоя, интрудированными межпластовыми телами долеритов [30]. Мощность перекрывающих трубку отложений составляет в среднем 66 м, в том числе трапповых тел -от 0,5 до 33,9 м. Погребённая поверхность огромной (69 га) трубки неровная, относительное превышение её северной части над южной - 44-48 м. Породы кратерной фации трубки Юбилейная представлены двумя толщами: верхней - осадочновулканогенной и нижней - туфогенной. В пределах верхних горизонтов чашеобразного расширения кратерной части преимущественное развитие имеют субгоризонтально залегающие осадочновулканогенные слабо литифицированные породы, слагающие почти полностью приповерхностную часть центрального рудного столба (до 85\% площади трубки). Мощность их колеблется от нескольких метров в краевых участках «чаши» до 150 м в её центральной части. Содержание обломочного материала вмещающих трубку отложений колеблется от нескольких до $60 \%$ их объема. Изредка в них встречаются ксенолиты глубинных пород и обломки порфировых кимберлитов, слагающих западный и восточный рудные столбы. Кратерные отложения залегают на размытой поверхности АКБ центрального рудного столба. Контакты между этими породами нечёткие и расплывчатые. В основании туфогенной толщи на контакте с подстилающими эруптивными брекчиями располагается зона, сложенная крупными (до 10 м) ксенолитами вмещающих пород (так называемый «ксенолитовый пояс»). В разрезе верхней части кратерных образований стратифицированные породы чередуются с нестратифицированными. Слоистые породы здесь имеют форму полос и линз, достигающих в длину нескольких десятков метров. Окраска пелитоморфных прослоев полностью зависит от цветового облика переотложенного материала. В этой части разреза часто наблюдаются зеркала скольжения, плоскость которых наклонена под острым углом к оси керна. Толща вулканогенно-осадочных пород подстилается туфами, которые представляют собой гетерогенную породу, сложенную дезинтегрированным материалом более ранних фаз внедрения кимберлитовыми лапиллями, выброс которых происходит синхронно или несколько раньше по отношению ко времени образованиия самой туфогенной толщи. По морфологическим особенностям и вещественному составу слагающих пород трубка Юбилейная представляет типичную воронку взрыва (центральная часть) и ряд дайкообразных тел (на флангах), формирующих в её структуре три обособленных «рудных столба». В разрезе центральный «рудный столб» имеет характерную трубчатую форму с чашеобразным расширением в пределах верхней кратерной части и близкую к округлой форму горизонтальных сечений. Западный и восточный «рудные столбы» представляют дайкообразные тела с извилистыми очертаниями как в плане, так и в вертикальных сечениях. В структуре трубки выделяются породы двух главных фаз внедрения: фланги сложены массивными порфировыми кимберлитами первой фазы, а центральный канал, начиная от основания чашеобразного расширения (с глубины 300 м и ниже), содержит автолитовые брекчии второй фазы [15]. По текстурно-структурным особенностям, вещественному составу и алмазоносности они близки между собой: это преимущественно плотные породы, окрашенные в серо-зелёный до тёмнозеленого цвета, с отчетливо выраженной порфировой структурой основной массы. В их составе отмечено большое количество псевдоморфоз по оливину, редких зерен пиропа и пикроильменита, сцементированных карбонат-серпентиновым агрегатом. Переходы между кимберлитовыми породами первой и второй фаз внедрения постепенные, через зону смешения материала мощностью от 0,5 до $30 \mathrm{~m}$. Наблюдается и неоднородная алмазоносность. Наиболее высокими содержаниями алмазов характеризуются кимберлитовые породы, залегающие под «чашей». Для последней характерно низкое содержание 
алмазов при повышенном количестве мелких кристаллов, особенно в верхних частях, где много неалмазоносного ксеногенного материала, образующего мелкозернистые породы.

Кимберлитовые трубки с эксплозивной камерой закрытого типа

Они обнаружены в ДААР СП (трубки Одинцова, Рот-Фронт, Якутская, обособленные мелкие тела около трубки Удачная и др.). Диатремы не имеют обычного открытого подводящего канала, достигающего соответствующей палеоповерхности, а поэтому представляют «полузакрытые» геологические образования. Так, кимберлитовая трубка Одинцова по форме приближается к дайкообразному телу, что связано с сопряженностью её с ослабленной тектонической зоной, существовавшей при внедрении кимберлитовой магмы. Диатрема приурочена к западному борту небольшого куполовидного поднятия, имеющего общую площадь в несколько квадратных километров и амплитуду порядка 30-45 м. Перекрыто тело эксплозивными карбонатными брекчиями, маломощными осадочными образованиями пермокарбона и интрузией долеритов мощностью до 80 м. Для трубки Одинцова характерно двухъярусное строение. Верхняя часть диатремы, получившая название «карбонатная шапка» [15], представляет переработанный эксплозивными процессами кимберлитовмещающий субстрат (карбонатные породы низов нижнего силура), превращенный в разнообломочные карбонатные брекчии. Ниже «карбонатной шапки» залегает собственно кимберлитовое тело, для которого характерна общая удлиненность, наличие расширяющегося кверху раструба с размером по вертикали 140x150 м и быстрый переход с глубиной сначала в подводящий канал в виде дайкообразного тела, а затем в серию тонких субпараллельных жил.
Кимберлитовые трубки, перекрытые маломощными элювиальными или делювиальными отложениями

Трубки были открыты на СП на первых этапах прогнозно-поисковых работ. Яркими поисковыми обьектами такого типа могут служить трубки Мир, Удачная и др. В зависимости от размеров кимберлитовых тел и особенностей их вещественного состава, как и геологического развития территории, такие диатремы могут по-разному выражаться в геофизических полях и формировать ореолы рассеяния в различной степени измененного кимберлитового материала. Кимберлитовые трубки Мир и Удачная, характеризующиеся крупными размерами и высокими концентрациями ИМК, при размыве давали чётко выраженные ореолы рассеяния, позволившие сравнительно легко направить геологов-исследователей на выявление материнских пород. Так, кимберлитовая трубка Мир вместе с трубкой Спутник [30] и системой даек приурочены к Параллельному глубинному разлому. Первая на поверхности имеет форму овала со слабым пережимом примерно в средней части. Размер её по длинной оси, ориентированной в северо-западном направлении, -490 м, по короткой -320 м. До глубины 200 м трубка представляет типичную воронку, глубже (до 900 м) - цилиндрическое тело с незначительным сужением книзу, а затем (в 900-1000 м от поверхности) она переходит в серию подводящих даек. Трубка прорывает терригенно-карбонатные и галогенно-карбонатные породы ордовика и кембрия, два силла (на глубине 500 и 1100-1200 м с мощностью соответственно 12-34 и 70 м) и дайку диабазов позднедевонского возраста. Терригенно-карбонатные породы представлены известняками, доломитами, мергелями, алевролитами и их переходными разностями. Сверху КВ кимберлитов трубки перекрывали маломощные четвертичные отложения. Верхние горизонты диатремы образовались в результа- 
те трёхфазного внедрения кимберлитового расплава [1-3,5-11,24]. КБ первой фазы слагают большую часть северо-западной половины трубки, в то время как аналогичные породы второй фазы на уровне современного эрозионного среза локализованы в её юго-западной части и инъецируют брекчии северо-западной половины диатремы. Кимберлитовые породы третьей фазы формируют на юго-востоке трубки вытянутое в северо-западном направлении дайковидное тело размером $30 \times 120$ м. Контакты этого тела с вмещающими кимберлитовыми брекчиями - секущие, а в самой зоне контакта широко развита сульфидная минерализация. В 131 м на северо-восток от трубки Мир открыта трубка Спутник, размером в плане 140x90 м. По степени выветрелости и постмагматического изменения среди кимберлитовых пород трубки выделяются несколько разновидностей. Кимберлиты трубки Мир богаты ИМК и алмазами. Учитывая большой эрозионный срез верхних частей месторождения (по разным исследованиям, до 350-400 м), отдельные разности древних осадочных толщ верхнего палеозоя, мезозоя и современные отложения МКП содержат повышенные концентрации ИМК, а иногда и самих алмазов.

\section{Обобщенная модель алмазоносной трубки ЯКП}

Несмотря на индивидуальность различных геолого-поисковых обстановок, а также каждого кимберлитового тела, между ними существует много общего, что позволило создать обобщенную модель алмазоносной трубки ЯКП, в которой нашли отражение как переход вертикального канала диатремы в подводящую дайку, так и особенности взаимоотношения этих обьектов с древними (девонскими) и более молодыми (пермотриасовыми) траппами, т.е. проследить характер сопряженности системы тел: главная трубка - сателлит - подводящая и дотрубочная дайки. На разведанную глубину трубок вмещающими её породами являются терригенно-карбонатные образования нижнего силура, нижнего, среднего и верхнего кембрия, представленные известняками, доломитами, мергелями, алевролитами и промежуточными разностями этих пород. В южной части СП (Мирнинское кимберлитовое поле) в значительном объёме разреза вмещающих трубки пород развиты пласты и линзы каменной соли. Особенно высокое содержание последних установлено в нижнекембрийских отложениях на глубине 9001200 м. Довольно часто встречаются также прослои и линзы гипса и ангидрита. В МБАР ряд кимберлитовых тел перекрыт нижнеюрскими осадочными толщами (песчаниками, алевролитами, слабо сцементированными гравийными и галечными образованиями), современная мощность которых колеблется от нескольких метров до 20. В отличие от этого, севернее СП в ДААР над частью кимберлитовых тел залегают терригенные пермскокаменноугольные образования мощностью до 100 м и более, представляющие сложное чередование алевролитов, песчаников, глинистых и углисто-глинистых сланцев, гравелитов и конгломератов. Верхнепалеозойский комплекс осадочных и вулканогенно-осадочных пород интрудирован многочисленными пластовыми и секущими телами траппов. В диатремовых кимберлитовых структурах выделяются (сверху вниз): а) раструб, венчающийся у неэродированных аппаратов кольцевым валом; б) вулканический (вертикальный) канал и в) корневая часть подводящий канал в виде дайкового тела. Каждая из этих частей кимберлитовых трубок сложена породами, имеющими определенные минералогические и текстурно-структурные особенности. Существенные закономерности в смене пород создают своеобразную вертикальную зональность коренных месторождений алмазов на каждой конкретной древней платформе. На СП ксенолиты кимберлитовых трубок делятся на четыре группы: a) осадочные породы платформенного чехла, являющиеся вмещающими для ди- 
атрем; б) изверженные - траппы, внедрившиеся в осадочный чехол до образования диатрем; в) метаморфические, слагающие фундамент платформы; г) глубинные, преимущественно мантийного происхождения. Содержание ИМК (пиропа, пикроильменита и хромшпинелидов) на глубоких уровнях их залегания выше, чем в самых верхних частях, хотя в различных трубках оно неодинаково. В верхних частях диатрем наиболее полных разрезов для осадочно-вулканогенных пород характерны выделения вторичных минералов в виде крупных жил, жеод, гнёзд и пр. В туфах и верхних горизонтах брекчий встречаются скопления крупных друз и прожилков кварца (в основном аметиста), кальцита и магнетита. Степень карбонатизации кимберлитов (как и в целом развития вторичных минералов) с глубиной существенно снижается. Существенное влияние на направленность и интенсивность развития вторичной минерализации в кимберлитах региона имеют состав и характер вмещающих трубки пород. Приведенные краткие сведения о геологическом строении и вещественном составе кимберлитов и вмещающих их пород СП показывают сложность геологоструктурных обстановок, которые необходимо учитывать при проведении прогнозно-поисковых работ на алмазы. Нередко поиски кимберлитовых диатрем представляют собой сложную задачу, особенно в случае отсутствия на таких участках продуктов дезинтеграции этих пород, что снижает результативность применяемого шлихо-минералоги-ческого метода. Существенно снижается и результативность геофизических методов поисков в случаях низкой намагниченности пород, слагающих диатремы, или перекрытия их мощными толщами магматических или осадочных пород. Надёжным методом при поисках таких диатрем может служить комплексное изучение структурно-текстурных особенностей и вещественного состава пород как вмещающего субстрата, так и самих диатрем и перекрывающих их отложений, особенно в случае образования в них алмазоносных россыпей. Особое внимание при этом следует уделять диагностике и определению типоморфных особенностей как первичных, так и вторичных минералов кимберлитов, учитывая при этом, что основная часть последних малоустойчива в процессе их транспортировки в водной среде, но даже при существенном изменении указывает на близкие расстояния перемещения от областей размыва. Важнейшая поисковая информация получается при изучении типоморфных особенностей самих алмазов и их парагенетических ассоциаций, характерных для конкретных кимберлитовых полей и диатрем. Пределами конкретных алмазоносных районов ограничиваются обычно распространения отдельных ассоциаций минералов в древних и современных осадочных образованиях. С помощью анализа распределения по площади и в разрезе типоморфных особенностей минералов и их парагенетических ассоциаций можно решать задачи определения источников их сноса в разновозрастные верхнепалеозойские и мезозойские отложения алмазоперспективных территорий. Особо следует отметить полигенность минералогических ассоциаций алмазов из разновозрастных россыпей в пределах отдельных алмазоносных районов (особенно МБАР и СреднеМархинского) с широким проявлением россыпной алмазоносности, достигающей иногда промышленной концентрации. Локальный прогноз их коренных источников возможен при более крупномасштабных исследованиях с использованием электронной базы данных с геологической привязкой, с привлечением и анализом всех имеющихся литолого-минералогических материалов по этим территориям. Внимание надо обращать на возможность развития в отдельных геолого-поисковых обстановках в верхних горизонтах кимберлитовых диатрем продуктов древних КВ, существенно меняющих петрофизические свойства исходных пород, что существенно затрудняет их поиски с применением геофизических методов. На при- 
мере комплексного изучения диатрем Накынского поля показана важность совершенствования методик прогнозирования и поисков немагнитных кимберлитовых диатрем, особенно перекрытых другими магматическими и осадочными породами. Наиболее уверенно и четко определять приуроченность отторженцев к материнским телам можно на основании сопоставления их вещественного состава (петрологических и минералогических особенностей).

\section{Библиографический список}

1. Аргунов К.П., Захарова В.Р., Зинчук Н.Н. Методическое руководство по изучению и использованию алмазов при типизации кимберлитовых трубок / Уралгеология. Свердловск, 1985. 105 с.

2. Аргунов К.П., Зинчук Н.Н. Онтогения алмазов // Исследование высокобарических минералов / ИФЗ АН СССР. М., 1987. C.166-186.

3. Афанасьев В.П., Зинчук Н.Н., Похиленко Н.П. Поисковая минералогия алмаза. Новосибирск: Изд-во «ГЕО», 2010. 650 с.

4. Бобриевич А.П., Бондаренко М.И., Гневушев M.A. и др. Алмазные месторождения Якутии. М.: Госгеолтехиздат, 1959. 515 с.

5. Бобриевич А.П., Илупин И.П., Козлов И.Т. и $\partial p$. Петрография и минералогия кимберлитовых пород Якутии. М.: Недра, 1964. $190 \mathrm{c}$.

6. Василенко В.Б., Зинчук Н.Н., Кузнецова Л.Г. Петрохимические модели алмазных месторождений Якутии. Новосибирск: Наука, 1997. 568 с.

7. Владимиров Б.М., Костровиикий С.И., Соловьева Л.В. и др. Классификация кимберлитов и внутреннее строение кимберлитовых трубок. М.: Наука, 1981. 136 с.

8. Егоров К.Н., Владимиров Б.М., Заборовский B.B. u $\partial p$. Калиевый трахит Далдынского кимберлитового поля (Якутия) // Проблемы кимберлитового магматизма. Новосибирск: Наука, 1989. С. 170-177.

9. Егоров К.Н., Зинчук Н.Н., Мишенин С.Г. и $\partial p$. Перспективы коренной и россыпной алмазоносности юго-западной части Сибирской платформы // Геологические аспекты минерально-сырьевой базы АК «АЛРОСА»: современное состояние, пер- спективы, решения / МГТ. Мирный, 2003. C. $50-84$.

10.Зайщев А.И., Корнилова В.П., Фомин А.С., Томшин М.Д. О возрасте кимберлитовых пород Накынского поля (Якутия) // Проблемы алмазной геологии и некоторые пути их решения / Воронеж. гос. ун-т. Воронеж, 2001. C.47-54.

11. Зинчук Н.Н. Коры выветривания и вторичные изменения кимберлитов Сибирской платформы (в связи с проблемой поисков и разработки алмазных месторождений) / Новосибир. гос. ун-т. Новосибирск, 1994. $240 \mathrm{c}$.

12. Зинчук Н.Н. Постмагматические минералы кимберлитов. М.: Недра, 2000. 538 с.

13. Зинчук Н.Н., Коптиль В.И. Типоморфизм алмазов Сибирской платформы. М.: Недра, 2003. 603 с.

14. Зинчук Н.Н., Котельников Д.Д., Борис Е.И. Древние коры выветривания и поиски алмазных месторождений. М.: Недра, 1983. $196 \mathrm{c}$.

15. Зинчук Н.Н., Савко А.Д., Крайнов А.В. Кимберлиты в истории Земли // Тр. НИИ геологии ВГУ: учеб. пособие / Воронеж. гос. ун-т. Воронеж, 2013. Вып. 68. 100 с.

16. Зинчук Н.Н., Савко А.Д., Шевырев Л.Т. Тектоника и алмазоносный магматизм / Воронеж. гос. ун-т. Воронеж, 2004. 426 с.

17. Зинчук Н.Н., Спечиус 3.В., Зуенко В.В., Зуeв B.M. Кимберлитовая трубка Удачная (вещественный состав и условия формирования) / Новосибир. гос. ун-т. Новосибирск, 1993. $147 \mathrm{c}$.

18. Зинчук Н.Н., Харькив А.Д., Мельник Ю.М., Мовчан Н.П. Вторичные минералы кимберлитов. Киев: Наукова думка, 1987. 282 c.

19. Илупин И.П., Каминский Ф.В., Францессон E.B. Геохимия кимберлитов. М.: Недра, $1978.352 \mathrm{c}$.

20. Каминский Ф.В. Закономерности размещения кимберлитовых (разнофациальных) и родственных им пород на Сибирской платформе // Докл. АН СССР. 1972. Т. 204, № 5. C.1187-1190.

21. Малич Н.С., Масайтис В.Л., Сурков В.С. Сибирская платформа. Л.: Недра, 1987. $431 \mathrm{c.}$

22. Маршинщев B.K. Вертикальная неоднородность кимберлитовых тел Якутии. Новосибирск: Наука, 1986. 239 с.

23. Милашев В.А. Кимберлитовые провинции. Л.: Недра, 1974. 224 с. 
24. Миламев В.А. Кимберлиты и глубинная геология. Л.: Недра, 1990. 167 с.

25. Никишов B.A. Петролого-минералогическая модель кимберлитового процесса. М.: Наука, 1984. 212 с.

26. Орлов Ю.Л. Минералогия алмаза. М.: Наука, 1984. 264 с.

27. Розен О.М,, Манаков А.В., Зинчук Н.Н. Сибирский кратон: формирование, алмазоносность. М.: Научный мир. 2006. 212 с.

28. Смелов А.П., Трофимов В.Ф., Зайцев А.И. Строение, этапы составления фундамента
Северо-Азиатского кратона и фанерозойский кимберлитовый магматизм // Геологические аспекты минерально-сырьевой базы акционерной компании «АЛРОСА»: современное состояние, перспективы, решения / МГТ. Мирный, 2003. С. 186-191.

29. Францессон Е.В., Лути Б.Г. Кимберлитовый магматизм древних платформ. М.: Недра, 1995. 342 с.

30. Харькив А.Д., Зинчук Н.Н., Крючков А.И. Коренные месторождения алмазов Мира. М.: Недра, 1998. 556 с.

\section{Geological and Petrographic Characteristics of Kimberlite Pipes}

\section{N.N. Zinchuk}

West-Yakutian Scientific Centre of the Sakha Republic Academy of Sciences, 4/1 Lenin Str., Mirny 678170, Russia. E-mail: nnzinchuk@rambler.ru

Studies of the geological structure and petro-chemical composition of the Siberian Platform kimberlites indicated complexity, diversity of geological, tectonic, and paleogeographic situations, which must be considered for proper prospectingexploration for diamonds in each area of investigation. Information about petrochemical composition of potential diatremes, hosting, and overlying sedimentary and magmatic formations is an important prerequisite for prospecting of kimberlite deposits in different geologic-tectonic conditions. The most attention should be paid to typomorphic specific features of primary and secondary minerals of diatremes. Each diamondiferous region is characterized by a certain set of typomorphic associations of kimberlites primary and secondary minerals. The diamonds with ultrabasic association of solid phase inclusions (olivine, chrome-spinel, pyrope, etc.) dominate in majority of kimberlite pipes.

Key words: kimberlites, pipes, Siberian Platform, diamondiferous region, typomorphism of minerals, diamonds.

\section{References}

1. Argunov K.P., Zakharova V.R., Zinchuk N.N. 1985. Metodicheskoe rukovodstvo po izucheniyu i ispolzovaniyu almazov pri tipizatsii kimberlitovykh trubok [Methodical handbook for study and application of diamonds for kimberlite pipes typification]. Uralgeologiya, Sverdlovsk, p. 105. (in Russian)

2. Argunov K.P., Zinchuk N.N. 1987. Ontogeniya almazov [Diamonds ontogeny]. In Investigation of high-barometric minerals. IFZ AN SSSR, Moskva, pp. 166-186. (in Russian)

3. Afanasiev V.P., Zinchuk N.N., Pokhilenko N.P. 2010. Poiskovaya mineralogiya almaza [Pro- specting mineralogy of diamond]. Geo, Novosibirsk, p. 650. (in Russian)

4. Bobrievich A.P., Bondarenko M.I., Gnevushev M.A. et al.1959. Almaznye mestorozhdeniya Yakutii [Diamond deposits of Yakutiya]. Gosgeoltechizdat, Moskva, p. 515. (in Russian).

5. Bobrievich A.P., Ilupin I.P., Kozlov I.T. et al. 1964. Petrografiya i mineralogiya kimberlitovykh porod Yakutii [Petrography and mineralogy of kimberlite rocks of Yakutia]. Nedra, Moskva, p. 190. (in Russian)

6. Vasilenko V.B., Zinchuk N.N., Kuznetsova L.G. 1964. Petrokhimicheskie modeli almaznykh mestorozhdeniy Yakutii [Petrochemical models of diamond deposits of Yakutia]. Nauka, Novosibirsk, p. 568. (in Russian) 
7. Vladimirov B.M., Kostrovitskiy S.I., Solovieva L.V. et al. 1981. Klassifikatsiya kimberlitov i vnutrennee stroenie kimberlitovykh trubok [Classification of kimberlites and internal structure of kimberlite pipes]. Nauka, Moskva, p. 136. (in Russian)

8. Egorov K.N., Vladimirov B.M., Zabarovskiy V.V. et al. 1989. Kalievyy trakhit Daldynskogo kimberlitovogo polya (Yakutiya) [Potassium trachyte of Daldyn kimberlite field (Yakutia)]. In Problems of kimberlite magmatism. Nauka, Novosibirsk, pp. 170177. (in Russian)

9. Egorov K.N., Zinchuk N.N., Mishenin S.G. et al. 2003. Perspektivy korennoy i rossypnoy almazonosnosti ygo-zapadnoy chasti Sibirskoy platform [Perspectives of primary and placer diamondiferousness of the southwestern part of Siberian Platform]. In Geological aspects of mineral-raw material base of OJSC ALROSA: modern state, perspectives, solutions. MGT, Mirnyy, pp. 50-84. (in Russian)

10. Zaitsev A.I., Kornilova V.P., Fomin A.S., Tomshin M.D. 2001. O vozraste kimberlitovykh porod Nakynskogo polya (Yakutiya) [About the age of kimberlite rocks of Nakyn field (Yakutia)]. In Problems of diamond geology and some ways of their solution. VSU, Voronezh, pp. 47-54. (in Russian)

11. Zinchuk N.N. 1994. Kory vyvetrivaniya i vtorichnye izmeneniya kimberlitov Sibirskoy platform ( $\mathrm{v}$ svyazi s problemoy poiskov i razrabotki almaznykh mestorozhdeniy) [Weathering crusts and secondary alterations of kimberlites of the Siberian Platform (in relation to the problem of exploration and development of diamond deposits)]. NSU, Novosibirsk, p. 240. (in Russian)

12. Zinchuk N.N. 2000. Postmagmaticheskie mineraly kimberlitov [Postmagmatic minerals of kimberlite]. Nedra, Moskva, p. 538. (in Russian).

13. Zinchuk N.N., Koptil V.I. 2003. Tipomorfizm almazov Sibirskoy platform [Typomorphism of the Siberian Platform diamonds]. Nedra, Moskva, p. 603. (in Russian)

14. Zinchuk N.N., Kotelnikov D.D., Boris E.I. 1983. Drevnie kory vyvetrivaniya i poiski almaznykh mestorozhdeniy [Ancient weathering crusts and prospecting of diamond deposits]. Nedra, Moskva, p. 196. (in Russian)

15. Zinchuk N.N., Savko A.D., Krainov A.V. 2013. Kimberlity v istorii Zemli [Kimberlites in the Earth history]. VSU, Voronezh, p. 100. (in Russian)

16. Zinchuk N.N., Savko A.D., Shevyrev L.T. 2004. Tektonika i almzonosnyy magmatism [Tectonics and diamondiferous magmatism]. VSU, Voronezh, p. 426. (in Russian)

17. Zinchuk N.N., Spetsius Z.V., Zuenko V.V., Zuev V.M. 1993. KImberlitovaya trubka Udachnaya (veshchestvennyy sostav i usloviya formirovaniya) [Kimberlite pipe Udachnaya (petrochemical composition and formation conditions)]. NSU, Novosibirsk, $p$. 147. (in Russian)

18. Zinchuk N.N., Kharkiv A.D., Melnik Y.M., Movchan N.P. 1987. Vtorichnye mineraly kimberlitov [Secondary minerals of kimberlites]. Naukova Dumka, Kiev, p. 282. (in Russian)

19. Ilupin I.P., Kaminskiy F.V., Frantsesson E.V. 1978. Geokhimiya kimberlitov [Geochemistry of kimberlites]. Nedra, Moskva, p.352. (in Russian).

20. Kaminsky F.V. 1972. Zakonomernosti razmeshcheniya kimberlitovykh (raznofatsialnykh) i rodstvennykh im porod na Sibirskoy platforme [Regularities of allocation of kimberlites (multiple facies) and related rocks on the Siberian Platform]. Doklady AN SSSR. 204(5):1187-1190. (in Russian)

21. Malich N.S., Masaytis V.L., Surkov V.S. 1987. Sibirskaya platforma [Siberian Platform]. Nedra, Leningrad, p. 431. (in Russian)

22. Marshintsev V.K. 1986. Vertikalnaya neodnorodnost kimberlitovykh tel Yakutii [Vertical heterogeneity of kimberlite bodies of Yakutiya]. Nauka, Novosibirsk, p. 239. (in Russian)

23. Milashev V.A. 1974. Kimberlitovye provintsii [Kimberlite provinces]. Nedra, Leningrad, p. 224. (in Russian)

24. Milashev V.A. 1990. Kimberlity i glubinnaya geologiya [Kimberlites and deep geology]. Nedra, Leningrad, p. 167. (in Russian)

25. Nikishov K.N. 1984. Petrologo-mineralogicheskaya model kimberlitovogo protsessa [Petro-mineralogical model of the kimberlite process]. Nauka, Moskva, p. 212. (in Russian)

26. Orlov Y.L. 1984. Mineralogiya almaza [Mineralogy of diamond]. Nauka, Moskva, p. 264. (in Russian)

27. Rozen O.M., Manakov A.V., Zinchuk N.N. 2006. Sibirskiy kraton: formirovanie, almazonosnost [Siberian craton: formation, dia- 
mondiferousness]. Nauchnyy mir, Moskva, p. 212. (in Russian)

28. Smelov A.P., Trofimov V.F., Zaitsev A.I. 2003. Stroenie, etapy sostavleniya fundamenta Severo-Aziatskogo kratona i fanerozoyskiy kimberlitovyy magmatism [Structure, stages of formation of the North-Asian craton basement and Phanerozoic kimberlite magmatism]. In Geological aspects of mineral base of OJSC ALROSA: modern state, per- spectives, solutions. MGT, Mirny, pp. 186191. (in Russian).

29. Frantsesson E.V., Lutz B.G. 1995. Kimberlitovyy magmatism drevnikh platform [Kimberlite magmatism of ancient platforms]. Nedra, Moskva, p. 342. (in Russian)

30. Kharkiv A.D., Zinchuk N.N., Kryuchkov A.I. 1998. Korennye mestorozhdeniya almazov mira [Primary diamond deposits of the World]. Nedra, Moskva, p. 556. (in Russian) 